\title{
Incorporation of untreated rice husk ash and water treatment sludge in masonry unit production
}

\author{
Sriranganathan Tharshika, Julian Ajith Thamboo* and Saranya Nagaretnam
}

\begin{abstract}
Conventional masonry units are made of clay with high temperature kiln firing or Ordinary Portland Cement (OPC) concrete mix. However, these conventional masonry unit production methods require intensive energy inputs and abundant raw materials. This predicament has led the researchers to look for sustainable methods of producing masonry units. Subsequently a research has been carried out to develop cement masonry unit incorporating Untreated Rice Husk Ash (URHA) and Water Treatment Sludge (WTS). Especially an attempted has been made to partially replace OPC and Quarry Dust (QD) by URHA and WTS, respectively. Totally nine different mix proportions of OPC, URHA, WTS and QD were used. The mechanical and durability characteristics of those masonry unit specimens were investigated to verify the suitability of the proportions. No significant changes in the mechanical and durability properties were noted in replacing OPC by URHA up to 15\%. However, replacement of QD by WTS considerably deteriorated the mechanical and durability properties. Therefore, it was proposed to incorporate maximum of 15\% URHA and WTS for the production of masonry unit as it complies with the strength requirements of EN 1996-1-1:2005 and EN 1998-1: 2005 for masonry structures.
\end{abstract}

Keywords: Masonry units, Untreated Rice husk ash, Water treatment sludge, Compressive strength, Water absorption, Porosity

\section{Introduction}

Manufacturing construction materials are increasingly becoming challenging due to the limited availability of raw materials and energy input concerns. The cement production alone account nearly $5-6 \%$ of total generated $\mathrm{CO}_{2}$ emissions [1, 2]. Therefore, the need for sustainable way of manufacturing construction materials has been discussed over the decades [3-6]. Particularly masonry is widely used in low and medium rise buildings around the world. The main constitutive material used in the masonry construction is the unit, which can be brick or block depending on the perforation percentages $[7,8]$. Commonly kiln fired clay bricks and Ordinary Portland Cement (OPC) concrete blocks are used as masonry units. However, production of these fired clay bricks and concrete blocks consumes intensive energy and raw

\footnotetext{
* Correspondence: jathamboo@seu.ac.lk

Department of Civil Engineering, South Eastern University of Sri Lanka, Oluvil 32360, Sri Lanka
}

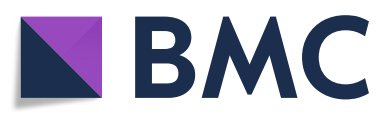

(c) The Author(s). 2019 Open Access This article is distributed under the terms of the Creative Commons Attribution 4.0 International License (http://creativecommons.org/licenses/by/4.0/), which permits unrestricted use, distribution, and reproduction in any medium, provided you give appropriate credit to the original author(s) and the source, provide a link to the Creative Commons license, and indicate if changes were made. The Creative Commons Public Domain Dedication waiver (http://creativecommons.org/publicdomain/zero/1.0/) applies to the data made available in this article, unless otherwise stated. materials, which has become an environmental concern in the present day world.

Therefore, this predicament has directed the researchers to shift their forces towards developing more sustainable masonry units from waste materials with less energy inputs. Turgut [9] and Zhang [10] have outlined various ways of manufacturing sustainable masonry units from past researches. Mostly the supplementary cementitious materials such as fly ash [11, 12], blast furnace slag $[13,14]$ and rice husk ash (RHA) $[15,16]$ were used to partially replace the OPC usage in the concrete/ cement masonry unit manufacturing. In particular, the rice husk is a major byproduct of the rice milling process. This agricultural waste is profusely available in all the rice producing countries. The RHA is produced by burning rice husks during biomass energy generation. The most important characteristic of RHA is the high amorphous silica content that determines the pozzolanic activity. Also RHA consists of high porous particles leading to a low bulk unit weight and high external surface 
area. RHA performs like fly ash and blast furnace slag with regard to its strength development in cementitious binders, however its higher silica content helps the pozzolanic reaction occur at later stages than the other supplementary cementitious materials [17].

A few studies have been carried out on using RHA for masonry unit manufacturing. Kazmi et al. [18] used RHA and waste sugarcane bagasse for clay brick production and found that $15 \%$ of RHA could be potentially used for unit manufacturing with reduction in density and increment in porosity. Gorhan and Simsek [19] have developed porous clay bricks with RHA and achieved compressive strengths of 7 to $10 \mathrm{MPa}$ with different proportions of mixes. It was commonly observed that the use of $20 \%$ RHA can possibly give acceptable strength and durability properties for masonry units [20,21]. However, the burning temperature and duration of the rice husk play an important role in the characteristics of RHA [22] as they determine the amorphous silica content. Therefore, directly utilising the untreated RHA (URHA) as cementitious material needs systematic investigation.

Instead of clay and natural aggregates, various industrial and agricultural wastes such as textile effluent [23], polystyrene foam [24], palm oil fuel ash [25], bio ashes [26], waste rubber [27], and waste paper pulps [28] were incorporated as fillers in masonry unit production. Also recycled construction demolition wastes were used to partly replace the natural aggregate in the masonry unit production [29]. Water treatment sludge (WTS) is a waste from the water treatment process. The increasing demand for treated water simultaneously produces significant amount of WTS for disposal and it is normally dumped in landfills. Therefore, using WTS as an aggregate in masonry unit production could be a prudent solution to alleviate the waste disposal problems.

Liew et al. [30] investigated the addition of sewage sludge ash into masonry unit production and suggested to use maximum of 20 to $30 \%$ of sludge ash instead of natural clay. Lin et al. [31] found that the incorporation of the sewage sludge ash up to $10 \%$ into a clay brick increases the water absorption and decreases the mechanical strength. Few more studies have been attempted to utilize the WTS for manufacturing construction materials [32, 33]. It is commonly reported that the WTS has a similar mineralogical composition to clay and addition of WTS over $15 \%$ increases the water absorption and reduces the mechanical strength of masonry unit.

Therefore, use of URHA and WTS into masonry unit production not only alleviates disposal problems of these industrial waste but also has economic, ecological and energy saving advantages. This research explores the possibility of producing masonry units by partially replacing OPC and natural aggregates by URHA and WTS, respectively. The quarry dust (QD) was used as the additional filler in this research. Nine different mix proportions of OPC, QD, URHA and WTS were investigated to determine the correct mix proportion suitable for masonry unit production. The density, porosity, water absorption, sorptivity, compressive strength, durability, and shrinkage characteristics of mix proportions were examined to decide the correct mix proportions for masonry unit production in this research.

\section{Materials}

OPC, QD, URHA, and WTS were used as the raw materials in this research. The characteristics of each material used in the research are briefly explained below.

\section{OPC}

OPC used in this research was classified as ASTM Type 1 cement. The specific gravity and Blaine fineness of the OPC were 3.12, and $320 \mathrm{~m}^{2} \mathrm{~kg}^{-1}$ respectively [34]. The particle size distribution (PSD) was determined using laser diffraction particle size analysing method, where the samples were dispersed through optical bench and the series of lasers beamed to measure the intensity of light scattered by the cement particles and later the scattered data was analysed using the instrument software to determine the PSD. The chemical composition of the OPC was determined through X-ray Analytical Microscope using X-ray fluorescence (XRF) method with high spatial resolution - from $1.2 \mathrm{~mm}$ down to $1 \mu \mathrm{m}$. The results of PSD and XRF analysis of OPC are in Fig. 1 and Table 1 respectively.

\section{URHA}

The URHA was obtained from Bio Energy Solution Limited, Sri Lanka. The acquired URHA in this research was heated between 600 to $800^{\circ} \mathrm{C}$ during the biomass production and no further treatment was carried out. The specific gravity and Blaine fineness of the URHA were 2.85 and $260 \mathrm{~m}^{2} \mathrm{~kg}^{-1}$ respectively. Figure 2a shows the scanning electron microscopy (SEM) image of URHA. The SEM image clearly indicates the presence of

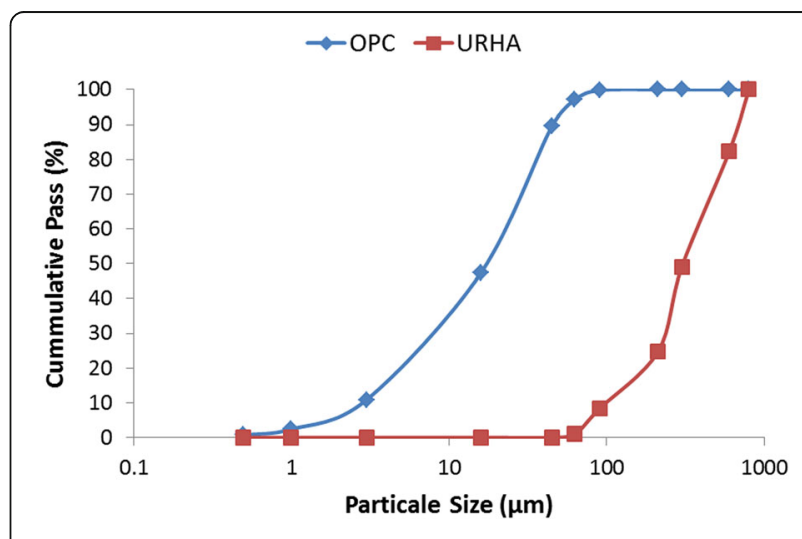

Fig. 1 Particle size distribution of OPC and URHA 
Table 1 Chemical composition of RHA and WTS

\begin{tabular}{llll}
\hline Elements & Mass \% in OPC & Mass \% in URHA & Mass \% in WTS \\
\hline $\mathrm{SiO}_{2}$ & 20.4 & 74.4 & 34.6 \\
$\mathrm{Al}_{2} \mathrm{O}_{3}$ & 6.1 & - & 24.3 \\
$\mathrm{~K}_{2} \mathrm{O}$ & 0.5 & 5.1 & 3.0 \\
$\mathrm{CaO}$ & 65.9 & 3.9 & 3.7 \\
$\mathrm{Fe}_{2} \mathrm{O}_{3}$ & 3.9 & 3.9 & 22.5 \\
$\mathrm{SO}_{3}$ & 1.3 & 0.7 & 2.8 \\
$\mathrm{TiO}_{2}$ & - & 0.7 & 0.4 \\
$\mathrm{MgO}^{2}$ & 0.6 & 0.8 & 1.9 \\
$\mathrm{LOl}^{\mathrm{a}}$ & 1.3 & 10.5 & 6.8 \\
\hline
\end{tabular}

${ }^{a} \mathrm{LOI}$ Loss on ignition

irregular and highly porous structure of URHA. The PSD analysis of URHA reveals that particle size of URHA varies between 100 to $800 \mu \mathrm{m}$. It can be said that URHA particles are coarser than the OPC used in this research. This is expected as the URHA was used

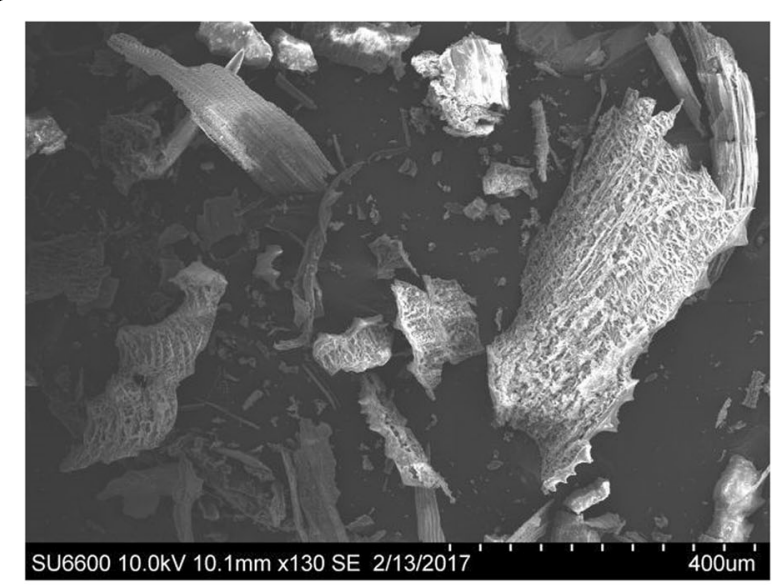

(a)

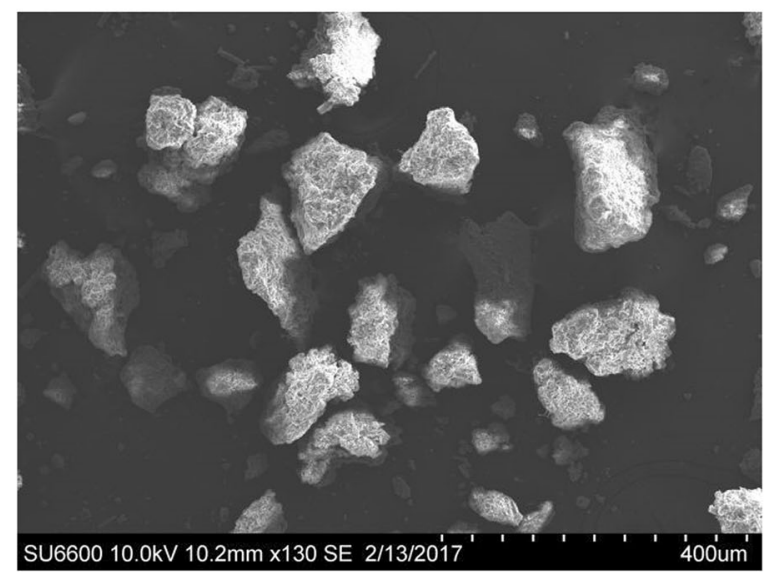

(b)

Fig. 2 Scanning electron microscopy (SEM) images of (a) RHA and (b) WTS without any pre-treatment or grinding in this research. The chemical composition of URHA is provided in Table 1. The XRF analysis reveals that the URHA contains considerable amount of silicon (74.4\%), potassium $(5.1 \%)$ and iron (3.9\%) oxides. It was noted that the loss on ignition is nearly $10 \%$, which could be due to the uncontrolled burning process (burning temperature fluctuated as mentioned before). Further the X-ray Diffraction (XRD) analysis of URHA was carried out using a standard bench top X-ray diffractometer. The XRD analysis depicted peaks at $12^{\circ}(2 \theta)$ and $24^{\circ}(2 \theta)$ that designate the predominantly silica existing in amorphous form in URHA.

\section{WTS}

The WTS was acquired from the nearby water treatment plant. The specific gravity of the WTS was 2.4. Figure $2 \mathrm{~b}$ shows the SEM image of WTS. It can be seen that the microstructure of WTS characterises the crystal structure in the form of stack of layers interspaced with the interlayers similar to clay structure [35]. The XRF analysis indicates silicon (34.6\%), aluminum (24.3\%) and iron (22.5\%) oxides (Table 1) in crystal form, similar to clay. Also the XRD analysis detected peaks at $28^{\circ}(2 \theta)$ and $36^{\circ}(2 \theta)$ that point to the silicate and aluminate present in WTS. Therefore, it could be said that the quartz and albite exist in WTS. The higher content of quartz and albite is justifiable as WTS was obtained as the residue of water treatment process, where the untreated river water would have higher content of suspended clay particles. The gradation of the WTS is presented in Fig. 3. Hydrometer analysis was carried out along with sieve analysis to determine the complete gradation of WTS. The calculated fineness modulus of WTS was 0.9.

QD

QD is produced in the quarries during aggregate crushing process as a by-product and widely used as a blend in the road sub-base construction. The measured specific gravity of the QD was 2.71. The sieve and hydrometer analysis were carried out to determine the gradation

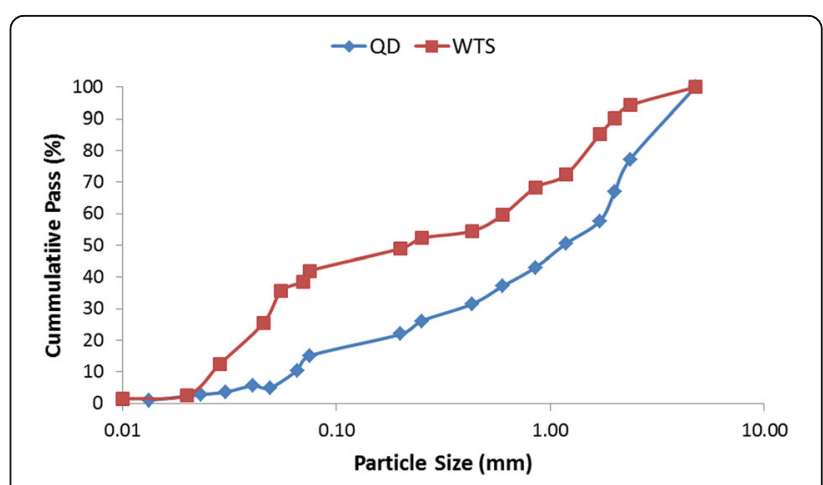

Fig. 3 Gradation of QD and WTS 
of QD. The gradation of selected QD is also shown in Fig. 3. Graded QD passing through $4.75 \mathrm{~mm}$ sieve with fineness modulus of 2.9 was used as aggregates in this research. Further, a comparable trend of gradation was observed between QD and WTS.

\section{Testing procedures}

All the mixes were made by volume proportion and no admixture was added during the mixing. The volume ratio between cementitious materials to aggregate was kept as 1:5 in all the trials. 1-L laboratory graduated cylinder was used to accurately measure the volume mix proportions. In order to correctly maintain the volume mixing, the masses of the added materials were also recorded while measuring volume for each proportion. Table 2 gives the volume mix trials and the corresponding mass proportions (for $1 \mathrm{~m}^{3} \mathrm{mix}$ ) used in this research. Additionally, the water to cement ratio $(\mathrm{w} / \mathrm{c})$ by mass of all the trials were fixed to 0.4 after a several mixing trials. The OPC, QD and water were initially mixed for nearly $3 \mathrm{~min}$ and then the WTS and URHA were later added to the mixes. Thereafter materials were thoroughly mixed for about 5 min prior to the samples preparation. The density, porosity, water absorption, sorptivity, compressive strength, durability and shrinkage properties of the trials were determined as the primary quality control testing methods for masonry unit production. In the following sections, those testing methods are briefly explained.

\section{Density measurement}

The dry density of hardened specimens was determined at 28-d of preparation. All the specimens were air cured. Four cubes of $70-\mathrm{mm}$ similar to compression testing specimens (explained later) were prepared to determine the dry density. Initially the specimens were completely immersed in water at room temperature $\left(28 \pm 2{ }^{\circ} \mathrm{C}\right)$ for $24 \mathrm{~h}$ and immersed masses were measured. Then the surface saturated mass (SSD) was taken after sponging off the damped surface. Later the specimens were dried in oven for $24 \mathrm{~h}$ and the constant dried masses were recorded. Finally, the dry density of each specimen was determined. Additionally, the difference in masses between the water saturated and dry conditions was used to calculate the apparent porosity as according to Eq. (1).

$$
\text { Porosity }=\frac{\text { SSD Mass }- \text { Dry Mass }}{\text { SSD Mass - Immersed Mass }}
$$

\section{Water absorption test}

The water absorption of masonry unit is one of the main parameters that affects the bond development with mortar. Also the water absorption of masonry units related to the durability of masonry structures. The water absorption of specimens was measured after 28-d of curing as per ASTM C140/C140M-17b [36]. Four 70-mm cube specimens were casted to determine the water absorption. Initially specimens were dried in oven at $60^{\circ} \mathrm{C}$ for $24 \mathrm{~h}$ to determine the dry masses. Later specimens were immersed in deionized water at room temperature for $24 \mathrm{~h}$. Then the mass changes were measured between the dry mass and constant saturated mass to determine the water absorption.

\section{Soprtivity test}

The sorptivity of cementitious material defines the rate of absorbing and transmitting water by capillary action. The method developed by Taha et al. [37] was used to determine the sorptivity of specimens in this research. Four rectangular prisms with the dimensions of $40 \times 40 \times 160 \mathrm{~mm}$ were cased. After $28 \mathrm{~d}$ of casting, specimens were dried in oven for $24 \mathrm{~h}$ to determine the dry mass. Afterward the longer sides of the specimens were wrapped with insulation tapes for waterproofing and unwrapped side of the specimens were immersed partially in the water to a depth of $5 \mathrm{~mm}$. Thereafter mass readings

Table 2 Mix proportions

\begin{tabular}{|c|c|c|c|c|c|c|c|c|}
\hline \multirow[t]{2}{*}{ Specimen } & \multicolumn{4}{|c|}{ Volume Ratio } & \multicolumn{4}{|c|}{ Mass Proportion } \\
\hline & OPC (\%) & URHA (\%) & QD (\%) & WTS (\%) & $\mathrm{OPC}\left(\mathrm{kg} \mathrm{m}^{-3}\right)$ & URHA $\left(\mathrm{kg} \mathrm{m}^{-3}\right)$ & $\mathrm{QD}\left(\mathrm{kg} \mathrm{m}^{-3}\right)$ & WTS $\left(\mathrm{kg} \mathrm{m}^{-3}\right)$ \\
\hline Trial 1 & 100 & 0 & 100 & 0 & 393 & 0 & 1706 & 0 \\
\hline Trial 2 & 95 & 5 & 100 & 0 & 373 & 17 & 1706 & 0 \\
\hline Trial 3 & 90 & 10 & 100 & 0 & 353 & 34 & 1706 & 0 \\
\hline Trial 4 & 85 & 15 & 100 & 0 & 333 & 51 & 1706 & 0 \\
\hline Trial 5 & 80 & 20 & 100 & 0 & 213 & 68 & 1706 & 0 \\
\hline Trial 6 & 95 & 5 & 95 & 5 & 373 & 17 & 1536 & 71 \\
\hline Trial 7 & 90 & 10 & 90 & 10 & 353 & 34 & 1366 & 142 \\
\hline Trial 8 & 85 & 15 & 85 & 15 & 333 & 51 & 1196 & 213 \\
\hline Trial 9 & 80 & 20 & 80 & 20 & 213 & 68 & 1026 & 284 \\
\hline
\end{tabular}


were taken at regular intervals $(t=5,10,15,30,45$ and 60 min) and the sorptivity was determined as per Eq. (2):

$$
i=S \sqrt{ } t
$$

where $S$ is the sorptivity, $i$ is the water absorption per unit area of inflow surface and $t$ is the elapsed time.

\section{Compression test}

Six cubes of $70 \mathrm{~mm}$ were casted to determine the unconfined compressive strength of the specimens. It was decided to cast only $70 \mathrm{~mm}$ cubes as masonry unit specimens rather than conventional size masonry units for compression test to ease the specimen preparation and testing. The compression testing was carried out after 28 $\mathrm{d}$ of casting. All the specimens were water cured for $14 \mathrm{~d}$ and remaining $14 \mathrm{~d}$ were air cured at room temperature. Compression testing machine of $1000 \mathrm{kN}$ with the loading rate of $0.5 \mathrm{~mm} \mathrm{~min}^{-1}$ was used for the testing. Plywood caps of $3 \mathrm{~mm}$ were inserted in between specimen and loading platens to reduce platen restrain effect between the specimen and loading platens. This plywood capping method is recommended in masonry unit testing standards such as ASTM C140/C140M-17b [36].

\section{Wetting and drying test}

The durability of specimens was determined by wetting-drying cyclic test as per ASTM D559/D559M-15 [38]. Four 70-mm cube specimens were casted to assess the durability of the trial mixes. After $28 \mathrm{~d}$ of curing, the specimens were submerged in deionized water at room temperature for $5 \mathrm{~h}$. Later they were dried in oven at $70^{\circ} \mathrm{C}$ for $48 \mathrm{~h}$ and thereafter air dried at room temperature for $3 \mathrm{~h}$. This process was considered as one cycle and the change in mass was recorded after each cycle. Subsequently the cycles were continued to record the change of mass until the specimens show resistance to mass loss.

\section{Shrinkage measurement}

ASTM C426-16 [39] was followed to determine the linear shrinkage of the trial mixes. Four shrinkage specimens per each trial were casted in the moulds of $40 \times 40 \times 160 \mathrm{~mm}$ dimension. Initially the lengths of the specimens were precisely measured and water saturated for $48 \mathrm{~h}$. Thereafter the specimens were dried in oven at $50{ }^{\circ} \mathrm{C}$ for $5 \mathrm{~d}$. Then the specimens were cooled at room temperature and the lengths were measured again. The change in length was considered as the linear shrinkage of the particular cycle. Thereafter the specimens were returned to the drying oven for of $48 \mathrm{~h}$. This process was continued until the recorded length change was negligible.

\section{Results and discussion}

The average density, water absorption, porosity, sorptivity and compressive strength measurements of the trials are given in Table 3. As stated before, the average values were determined by testing at least four samples for each property and trial, except the compressive strength, where the six samples were tested each trial. The coefficients of variations (\%) are given in parentheses.

\section{Density}

The dry density of the trials varied between 1716 and $2182 \mathrm{~kg} \mathrm{~m}^{-3}$. The results indicate replacement of URHA up to $20 \%$ did not considerably change the density of the specimens. However, the introduction of $20 \%$ WTS has reduced the dry density by $35 \%$ compared to the reference trial. This is due to the fact that the WTS had lower specific gravity than QD. All these specimens (Except trials 8 and 9) could be regarded as dense aggregate units as according to ASTM C55-16 [40] as their densities were above $2000 \mathrm{~kg} \mathrm{~m}^{-3}$. The trials 8 and 9 can be regarded as medium weight masonry units as their densities were within 1680 to $2000 \mathrm{~kg} \mathrm{~m}^{-3}$ range.

\section{Water absorption and porosity}

It can be seen no significant changes in water absorption with the replacement of OPC by URHA in the trials.

Table 3 Testing results

\begin{tabular}{llllll}
\hline Specimen & Density $\left(\mathrm{kg} \mathrm{m}^{-3}\right)$ & Water absorption (\%) & Porosity (\%) & Sorptivity $\left(\mathrm{g} \mathrm{mm}^{-2} \mathrm{~min}^{-0.5}\right)$ & Compressive Strength (MPa) \\
\hline Trial 1 & $2130(0.6)$ & $7.7(3.9)$ & $16.4(3.3)$ & $0.0014(7.2)$ & $22.3(2.1)$ \\
Trial 2 & $2107(3.3)$ & $7.8(1.5)$ & $16.5(1.6)$ & $0.0013(15.3)$ & $22.8(8.9)$ \\
Trial 3 & $2162(0.9)$ & $7.2(3.3)$ & $15.6(2.5)$ & $0.0013(15.3)$ & $23.0(5.2)$ \\
Trial 4 & $2182(0.3)$ & $6.8(2.5)$ & $14.9(2.3)$ & $0.0014(7.2)$ & $24.7(2.8)$ \\
Trial 5 & $2076(1.1)$ & $7.9(1.4)$ & $16.4(0.9)$ & $0.0013(15.3)$ & $20.9(2.7)$ \\
Trial 6 & $2057(1.3)$ & $7.0(3.1)$ & $14.3(2.6)$ & $0.0014(7.2)$ & $17.2(2.6)$ \\
Trial 7 & $2022(0.3)$ & $7.9(2.6)$ & $16.0(2.3)$ & $0.0014(7.2)$ & $15.8(5.9)$ \\
Trial 8 & $1886(0.8)$ & $9.7(5.9)$ & $18.3(5.2)$ & $0.0015(6.7)$ & $6.8(8.1)$ \\
Trial 9 & $1716(0.6)$ & $13.8(1.5)$ & $19.0(1.6)$ & $0.0017(17.6)$ & $1.5(14.6)$ \\
\hline
\end{tabular}


However, the partial introduction of WTS by $20 \%$ in the trial has increased the water absorption by $100 \%$ compared to the reference trial. This is due to the high water absorption and retention characteristics of WTS, which has higher content of clay. Additionally, the partial usage of WTS has increased the porosity of the trials. This could be due to the poor bond development between WTS and cementitious nature in the trials. The ASTM C55-16 [40] specifies that the dense and medium weight masonry units should have maximum water absorption of 8 and $11.3 \%$ respectively. Therefore, expect for the trial 9 (20\% URHA and 20\% WTS), all other trials satisfy the requirement in terms of water absorption for masonry unit production.

\section{Sorptivity}

No significant change in soprtivity was noted among the trial 1 to trail 8 as they vary between 0.0013 to $0.0015 \mathrm{~g} \mathrm{~mm}^{-2} \mathrm{~min}^{-0.5}$. However, sorptivity of the trial 9 was $0.0017 \mathrm{~g} \mathrm{~mm}^{-2} \mathrm{~min}^{-0.5}$. The increase in sorptivity of trial 9 could be due to the higher WTS content in the trail.

\section{Compressive strength}

The replacement of URHA did not significantly alter the compressive strength at $28 \mathrm{~d}$. Only the URHA addition of $15 \%$ specimen (Trial 4) has slightly increased the compressive strength by $10 \%$ compared to reference trial 1. Further addition of URHA up to $20 \%$ reduces the compressive strength by $15 \%$. Similar results were reported in previous studies $[41,42]$. This phenomenon is due to excessive amount of amorphous silica present in URHA which is higher than that for required reaction. Therefore, the excessive silica replaces part of the cement and does not contribute to the strength gain. Further the reduction of the compressive strengths is also justified by the reduction in the densities of the trials.

Moreover, the introduction of WTS has considerably reduced the compressive strength of the specimens. The replacement of WTS beyond 15\% to QD did not produce acceptable compressive strength as it dropped to 1.54 $\mathrm{MPa}$. The combination of excessive URHA and WTS in trail 9, could have contributed poor hydration process and bond between cementitious paste and aggregates.

The minimum compressive strength of masonry unit specified in ASTM C55-16 [40] for load-bearing walls construction is $13.1 \mathrm{MPa}$. Therefore, expect the trials 8 and 9, all other trials comply the above compressive strength requirement. As according to ASTM C129-17 [43], a non-loading masonry unit should have minimum of 3.45 MPa compressive strength. Therefore, the trial 9 fails even to qualify as non-loading masonry unit in this research.

The BS EN 1996-1-1 [7] outlines to use the normalized strength of masonry units for design. The normalized strengths of units take into account the shape factor (i.e., height to width relationship) as there are many sizes of masonry units available in the market, where the compressive strength of any size of the masonry unit is covered to normalized compressive strength (i.e., $100 \mathrm{~mm}$ height $\times 100 \mathrm{~mm}$ width). To obtain the normalized strength, the mean strength should be corrected as according to BS EN 771-3 [44] based on the aspect ratio of the developed units (in this case 70 $\mathrm{mm}$ height to width). Therefore, the mean compressive strengths obtained in this investigation were multiplied by 0.94 (obtain from BS EN 771-3 [44]) as the tested specimens were only $70 \mathrm{~mm}$ cubes. Further BS EN 1996-1-1 [7] and BS EN 1998-1 [45] state that the allowable minimum compressive strength of masonry design should be $5 \mathrm{MPa}$. Therefore, except trial 9, all other trials have given normalized compressive strengths more than $5 \mathrm{MPa}$. Since masonry is commonly used for typical low-rise building structures, the minimum compliance 5 $\mathrm{MPa}$ could be more appropriate for the selection of masonry unit in most design situations. Therefore, it could be said that the optimal level of replacement of URHA and WTS could be $15 \%$ for masonry unit production from the trials tested in this research.

\section{Wetting and drying}

Figure 4 shows the variation of weight loss of the trials with cyclic wetting-drying. The cumulative weight losses of the trials after tenth cycle were in the range of 0.47 (reference trial) to $2.5 \%$. In general, the cumulative weight loss increased up to six wetting-drying cycles for all trials. Beyond the sixth $\mathrm{w}-\mathrm{d}$ cycle, the weight loss almost became constant for trials 1 to 6 (i.e., only 5\% URHA and WTS replacement). It can be seen that there is no significant weight loss difference observed among trials 1 to 5 . However cumulative weight loss of trial 6 is almost double that of trial 1. Nevertheless, the trials 7 and 8 demonstrated continuous weight loss up to eighth cycle and stopped after the tenth cycle. However, the trial 9 mixes depicted continuous weight loss up $2.5 \%$ after tenth cycle. The ASTM D559/D559M-15 [38] does not clearly specify any limitation for the weight loss percentage; however, the weight loss of trail 9 is not acceptable in the context of masonry construction as it mostly exposed to external weathering.

\section{Shrinkage}

Figure 5 shows the drying shrinkage characteristics of the trials. The values of drying shrinkage varied from 0.018 to $0.19 \%$. It can be clearly seen that the shrinkages of URHA and WTS replaced trials were higher than that of the reference trial. However, their shrinkage trend became constant after the fifth cycle of repetitive cooling and drying process. The usage of URHA has increased the shrinkage of the specimens. This could be due to the 


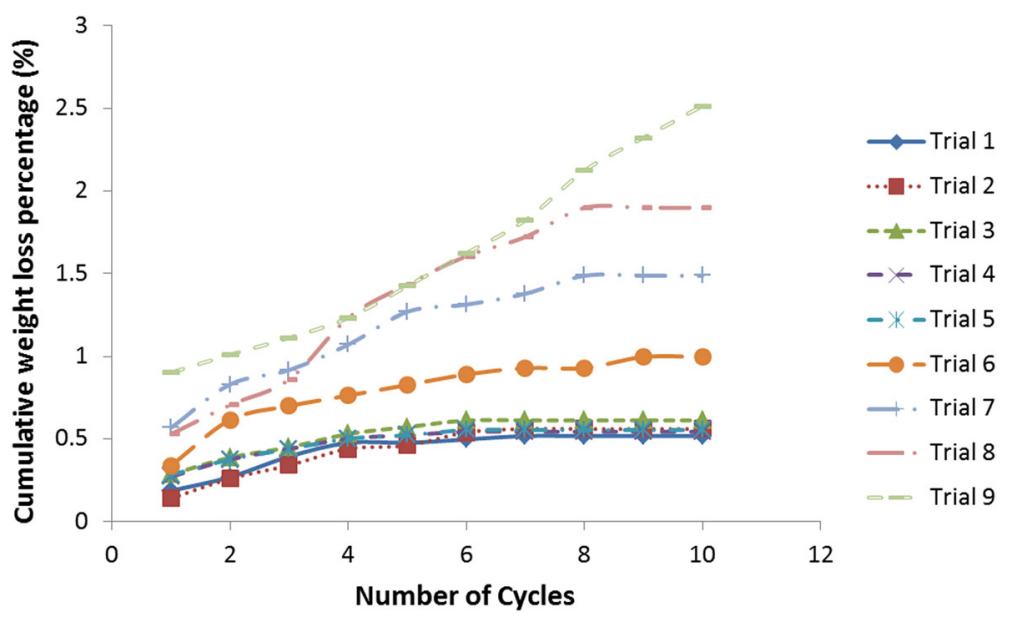

Fig. 4 Durability characteristics of different trials

higher porous nature of URHA, which contributed to the higher shrinkage while continuous hydration. Also introduction of WTS also degraded the shrinkage characteristics of the trials. It can be noted that the usage of $20 \%$ WTS along with 20\% URHA (trial 9) exhibited the highest shrinkage characteristics in the research.

\section{Micro-structural analysis}

Figure 6 shows the SEM images and Energy dispersive X-ray (EDX) analysis of trial 1, trial 5 and trial 9 specimens. Only these three trial specimens were considered for SEM and EDX study as they were considered the most significant among all trials (Trial 1 is the reference, Trial 5 has the highest URHA addition and Trial 9 has the highest URHA and WTS usage). The analyses were carried out after $28 \mathrm{~d}$ of casting. The samples were dried at critical point and gold coated prior to SEM analysis. The focused areas of the SEM images and EDX analysis were at the aggregate and cementitious paste interfaces (Indicated in white box). It can be seen from the Fig. $6 a$ and $b$ that the microstructure of trial 1 and 2 specimens is homogeneous and densely formed. Also SEM images clearly show the $\mathrm{C}-\mathrm{S}-\mathrm{H}$ and $\mathrm{C}-\mathrm{A}-\mathrm{H}$ formation and their presence in the chemical composition was supported by EDX spectrums. The EDX analysis detected nearly similar amount of silica, calcium, aluminum, potassium and sodium compounds in both trials. Therefore, it can be pulsated that use of URHA up to $20 \%$ in cement alone increased the silica content sufficiently which also increased the formation of C-S-H products. This justifies the analogues mechanical and durability properties of both trials.

Loose cement paste and aggregate bonding can be visible in Fig. 6c of trial 9 specimen. Addition of $20 \%$ URHA and 20\% WTS have increased the amorphous silica and aluminum content leading to excessive unreactive particles in the trial 9. With excessive silica, the

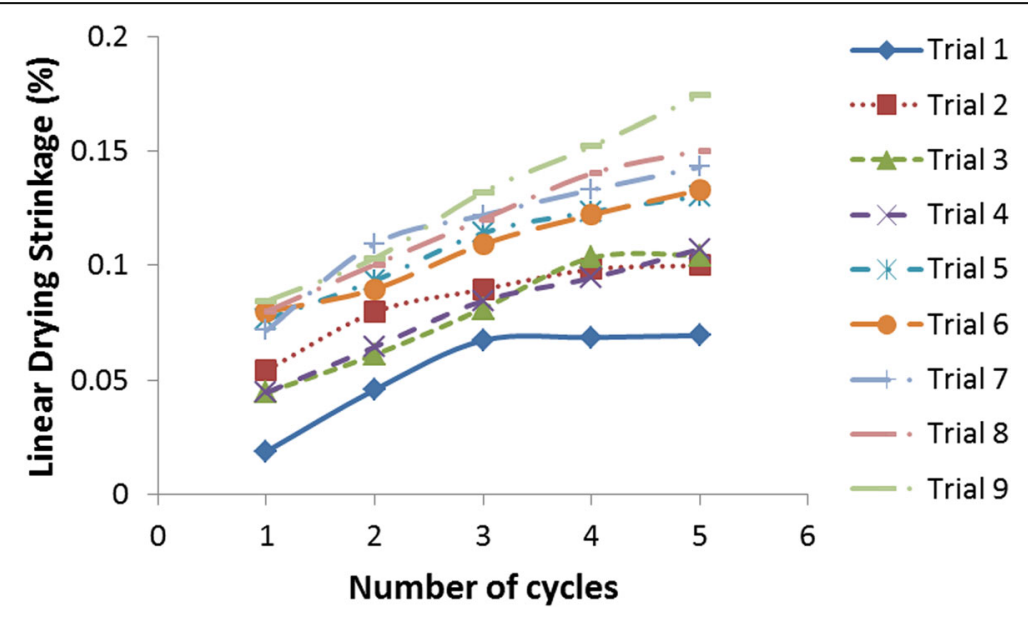

Fig. 5 Drying shrinkage of different trials 


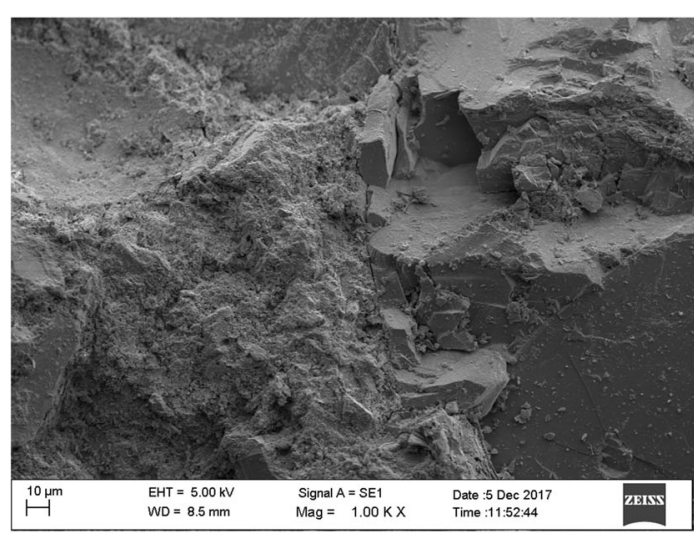

(a)
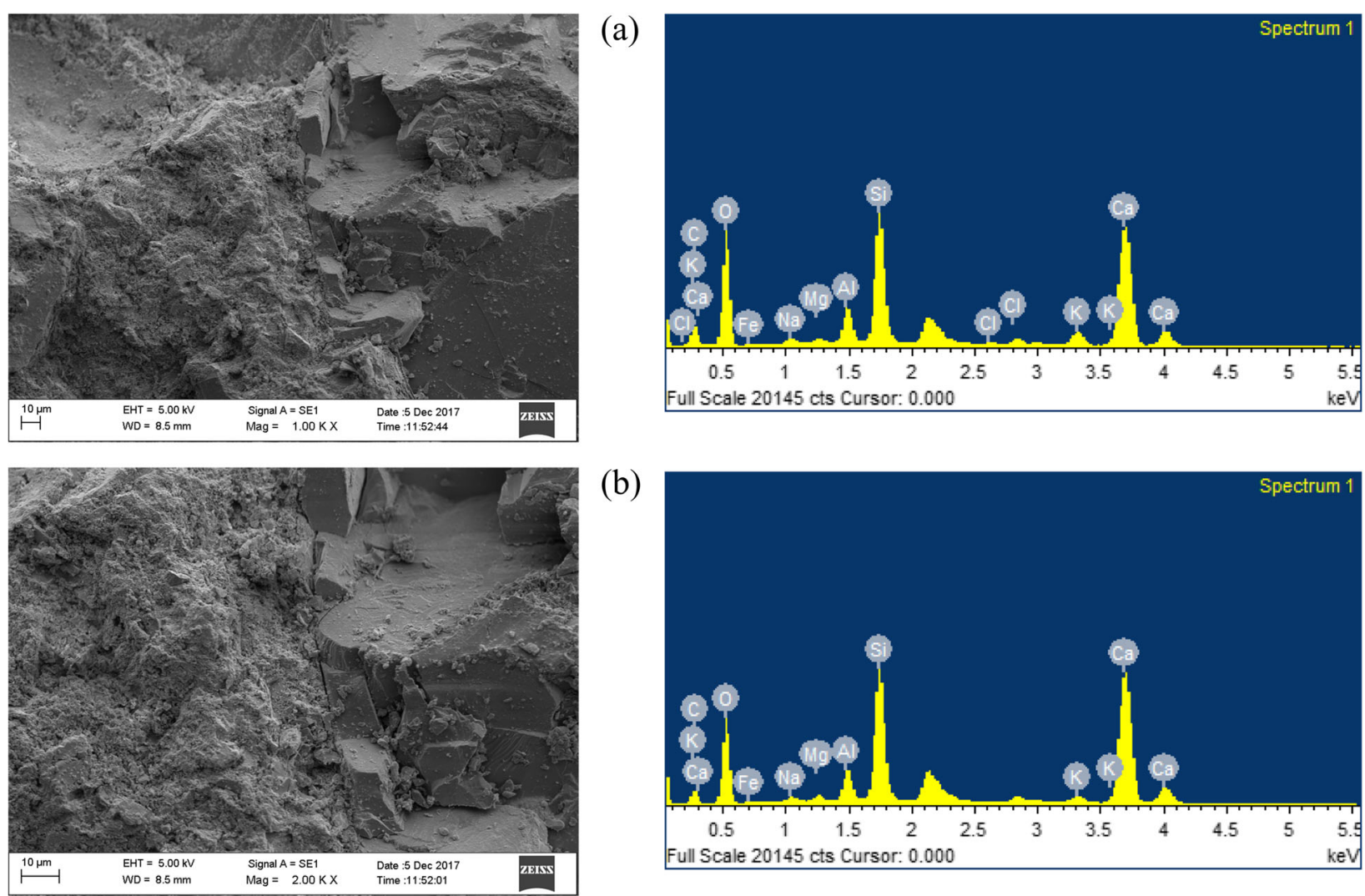

(b)
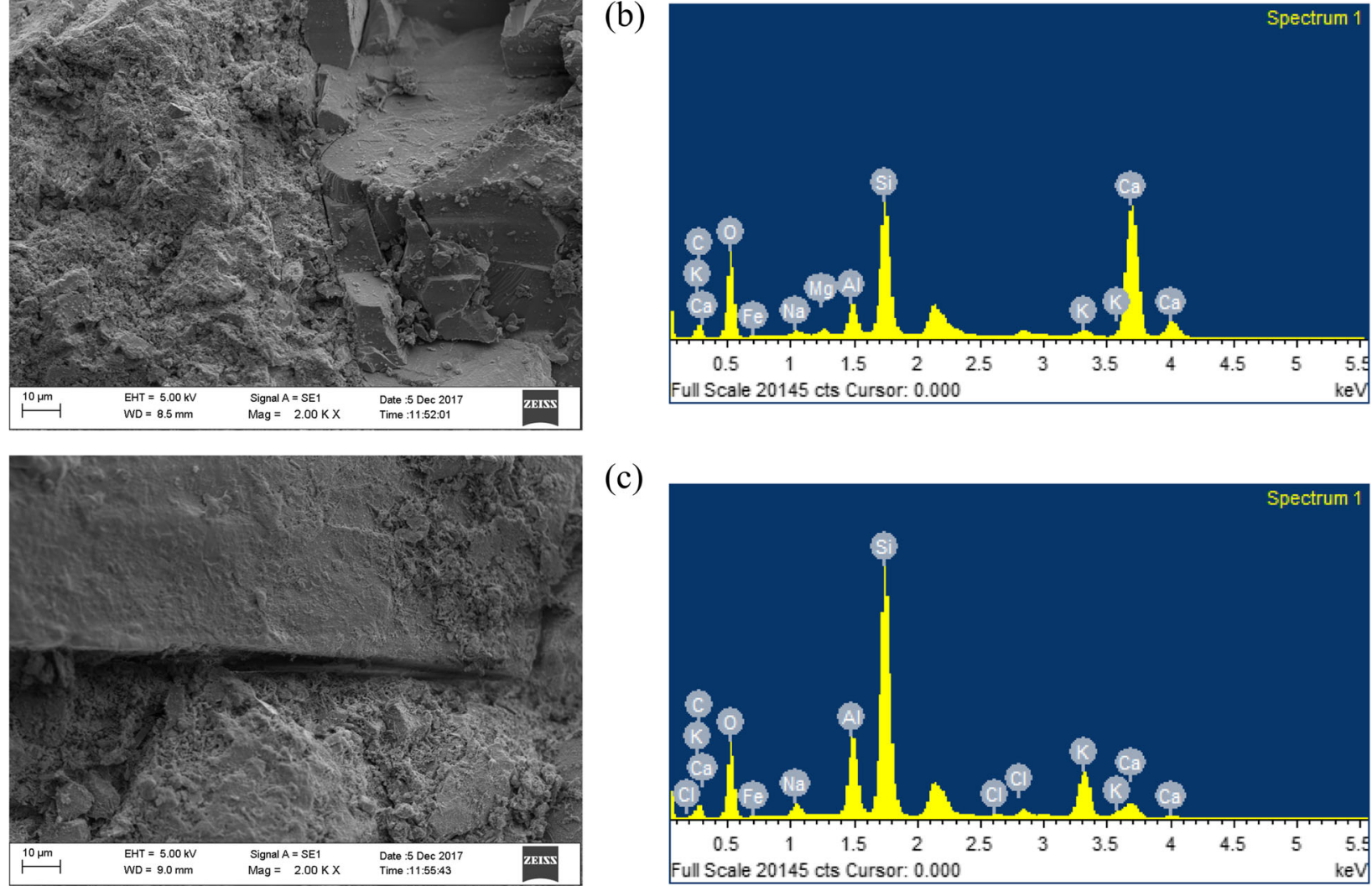

(c)

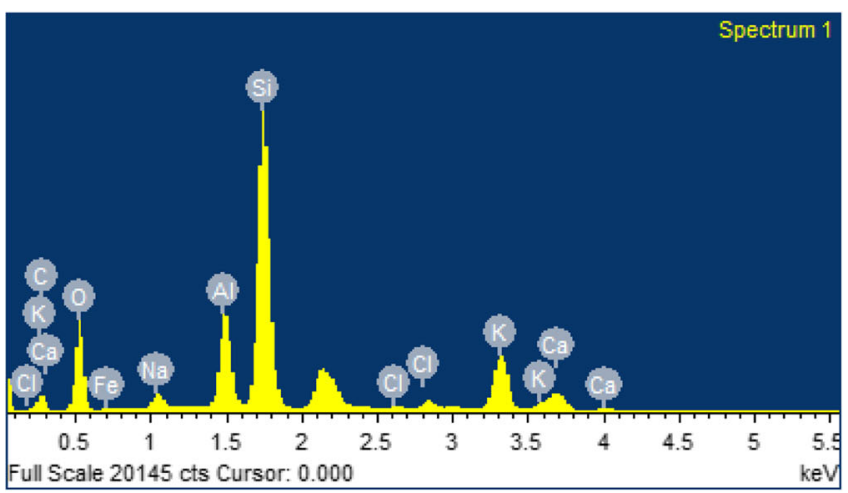

Fig. 6 SEM image and EDX analysis of specimens (a) Trial 1 (b) Trial 5 and (c) Trial 9

microstructure of trial 9 mix became looser with more pores and cracks. The cracks always appeared on the interface between the aggregate and the paste, which lowered bond between them. This phenomenon was signified by EDX spectrum of trail 9 that the excessive silica and aluminum had lowered the calcium content, which consequently reduced the formation of $\mathrm{C}-\mathrm{S}-\mathrm{H}$ and $\mathrm{C}-\mathrm{A}-\mathrm{H}$. Also the excessive unreacted silica particles could have acted as inert, subsequently reduce the strength properties of the trail. Therefore, the SEM and EDX analysis of trial 9 samples is well in agreement with the strength and durability results.

\section{Summary and conclusions}

The use of industrial wastes such as of URHA and WTS as raw materials to produce masonry units contributes to the sustainable development. The research shows that the incorporation of URHA and WTS to manufacture masonry bricks is feasible. Initially the chemical composition of raw materials was analysed through SEM, XRF and XRD examinations. Thereafter nine different volume proportions of OPC, QD, URHA and WTS were trialed to find the correct mix proportion to produce masonry units in this research. Furthermore, the mechanical and durability characteristic testing 
relevant to masonry unit production was carried out. The following conclusions can be drawn based on the experimental results:

- Incorporation of URHA and WTS into masonry unit production is a feasible approach.

- Introduction of the URHA up to $20 \%$ to OPC does not significantly change the density of the mixes. However, the replacement level of WTS reduces density of the different mix proportions.

- The water absorption and porosity of increase with increase of WTS percentage.

- All the trials satisfy the compressive strength of masonry unit provision of BS EN 1996-1-1 (2005) and BS EN 1998-1 (2005) for masonry structures, except the trial 9, which has 20\% URHA and WTS replacements.

- The durability test of cyclic wetting and dry showed that the incorporation of 20\% URHA and WTS was not suitable for masonry unit as it showed continuous weight loss. Otherwise additional measures should be taken to protect the surface of those units from weathering.

- The shrinkage of trials was constant after the fifth cycles of repetitive cooling and drying process. However, the addition of 20\% URHA and WTS depicted higher shrinkage than that of other trials investigated.

Therefore, it could be generally inferred that the possible usage of URHA and WTS could be 15\% based on the mechanical and durability tests carried out in this research. However, the 15\% optimization could slightly vary depending on the types/sources of the URHA and WTS for masonry unit production.

\section{Acknowledgements}

The authors thank the South Eastern University of Sri Lanka for the financial support to this project (under the research grant of SEU/ASA/RG/2016/01) and provided technical support. The assistance from the industry partners Bio Energy Solution (Pvt) Limited for providing untreated rice husk ash and National Water Supply and Drainage Board (NWSDB) for supplying waters treatment sludge are gratefully acknowledged.

\section{Authors' contributions}

ST carried out the experimental works. JT coordiated the research work and wrote the paper. SN also contributed in the experimental works. All authors read and approved the final manuscript.

\section{Competing interests}

The authors declare that they have no competing interests.

\section{Publisher's Note}

Springer Nature remains neutral with regard to jurisdictional claims in published maps and institutional affiliations.
Received: 30 August 2018 Accepted: 7 January 2019

Published online: 17 April 2019

\section{References}

1. Akan MOA, Dhavale DG, Sarkis J. Greenhouse gas emissions in the construction industry: an analysis and evaluation of a concrete supply chain. J Clean Prod. 2017;167:1195-207.

2. Rodrigues FA, Joekes I. Cement industry: sustainability, challenges and perspectives. Environ Chem Lett. 2011;9:151-66.

3. Hill RC, Bowen PA. Sustainable construction: principles and a framework for attainment. Constr Manag Econ. 1997;15:223-39.

4. Horvath A. Construction materials and the environment. Annu Rev Environ Resour. 2004;29:181-204.

5. Ortiz O, Castells F, Sonnemann G. Sustainability in the construction industry: a review of recent developments based on LCA. Constr Build Mater. 2009; 23:28-39.

6. Raut SP, Ralegaonkar RV, Mandavgane SA. Development of sustainable construction material using industrial and agricultural solid waste: a review of waste-create bricks. Constr Build Mater. 2011;25:4037-42.

7. EU. Eurocode 6: Design of Masonry Structures - Part 1-1: General Rules for Reinforced and Unreinforced Masonry Structures. Brussels: European Union; 2005.

8. Thamboo JA, Dhanasekar M, Yan C. Effects of joint thickness, adhesion and web shells to the face shell bedded concrete masonry loaded in compression. Aust J Struct Eng. 2013:14:291-302.

9. Turgut P. Manufacturing of building bricks without Portland cement. J Clean Prod. 2012;37:361-7.

10. Zhang LY. Production of bricks from waste materials - a review. Constr Build Mater. 2013;47:643-55

11. Saha AK. Effect of class F fly ash on the durability properties of concrete. Sustain Environ Res. 2018;28:25-31.

12. Kumar S. A perspective study on fly ash-lime-gypsum bricks and hollow blocks for low cost housing development. Constr Build Mater. 2002;16:519-25.

13. Xu LL, Guo W, Wang T, Yang NR. Study on fired bricks with replacing clay by fly ash in high volume ratio. Constr Build Mater. 2005;19:243-7.

14. Oti JE, Kinuthia JM, Bai J. Using slag for unfired-clay masonry-bricks. P I Civil Eng-Constr Mater. 2008;161:147-55

15. Sadek DM. Effect of cooling technique of blast furnace slag on the thermal behavior of solid cement bricks. J Clean Prod. 2014;79:134-41.

16. Raut S, Ralegaonkar R, Mandavgane S. Utilization of recycle paper mill residue and rice husk ash in production of light weight bricks. Arch Civ Mech Eng. 2013;13:269-75.

17. Sua-iam G, Makul N. Utilization of high volumes of unprocessed lignite-coal fly ash and rice husk ash in self-consolidating concrete. J Clean Prod. 2014; 78:184-94.

18. Kazmi SMS, Abbas S, Saleem MA, Munir MJ, Khitab A. Manufacturing of sustainable clay bricks: utilization of waste sugarcane bagasse and rice husk ashes. Constr Build Mater. 2016;120:29-41.

19. Gorhan G, Simsek O. Porous clay bricks manufactured with rice husks. Constr Build Mater. 2013;40:390-6.

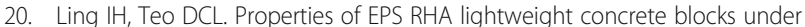
different curing conditions. Constr Build Mater. 2011;25:3648-55.

21. Hwang $\mathrm{CL}$, Huynh TP. Investigation into the use of unground rice husk ash to produce eco-friendly construction bricks. Constr Build Mater. 2015;93:335-41.

22. Bie RS, Song XF, Liu QQ, Ji XY, Chen P. Studies on effects of burning conditions and rice husk ash (RHA) blending amount on the mechanical behavior of cement. Cem Concr Compos. 2015;55:162-8.

23. Zhan BJ, Poon CS. Study on feasibility of reutilizing textile effluent sludge for producing concrete blocks. J Clean Prod. 2015;101:174-9.

24. Xu Y, Jiang LH, Xu JX, Li Y. Mechanical properties of expanded polystyrene lightweight aggregate concrete and brick. Constr Build Mater. 2012;27:32-8.

25. Faria KCP, Gurgel RF, Holanda JNF. Recycling of sugarcane bagasse ash waste in the production of clay bricks. J Environ Manag. 2012;101:7-12.

26. Sakhare W, Ralegaonkar RV. Use of bio-briquette ash for the development of bricks. J Clean Prod. 2016;112:684-9.

27. Gheni AA, Eigawady MA, Myers JJ. Thermal characterization of cleaner and eco-efficient masonry units using sustainable aggregates. J Clean Prod. 2017:165:980-93.

28. Raut SP, Sedmake R, Dhunde S, Ralegaonkar RV, Mandavgane SA. Reuse of recycle paper mill waste in energy absorbing light weight bricks. Constr Build Mater. 2012;27:247-51. 
29. Xu SQ, Wang JL, Jiang Q, Zhang S. Study of natural hydraulic lime-based mortars prepared with masonry waste powder as aggregate and diatomite/ fly ash as mineral admixtures. J Clean Prod. 2016;119:118-27.

30. Liew AG, Idris A, Wong CHK, Samad AA, Noor MJMM, Baki AM. Incorporation of sewage sludge in clay brick and its characterization. Waste Manag Res. 2004;22:226-33.

31. Lin KL, Lo KW, Hung MJ, Cheng TW, Chang YM. Recycling of spent catalyst and waste sludge from industry to substitute raw materials in the preparation of Portland cement clinker. Sustain Environ Res. 2017;27:251-7.

32. Horpibulsuk S, Suksiripattanapong C, Samingthong W, Rachan R, Arulrajah A. Durability against wetting-drying cycles of water treatment sludge-fly ash geopolymer and water treatment sludge-cement and silty clay-cement systems. J Mater Civil Eng. 2016;28:04015078.

33. Bin Anwar T, Behrose B, Ahmed S. Utilization of textile sludge and public health risk assessment in Bangladesh. Sustain Environ Res. 2018:28:228-33.

34. ASTM. Standard Test Methods for Fineness of Hydraulic Cement by AirPermeability Apparatus. West Conshohocken: American Society for Testing and Materials International; 2018.

35. Hamidi S, Marandi SM. Clay concrete and effect of clay minerals types on stabilized soft clay soils by epoxy resin. Appl Clay Sci. 2018;151:92-101.

36. ASTM. Standard Test Methods for Sampling and Testing Concrete Masonry Units and Related Units. West Conshohocken: American Society for Testing and Materials International; 2017

37. Taha MMR, El-Dieb AS, Shrive NG. Sorptivity: a reliable measurement for surface absorption of masonry brick units. Mater Struct. 2001;34:438-45.

38. ASTM. Standard Test Methods for Wetting and Drying Compacted SoilCement Mixtures. West Conshohocken: American Society for Testing and Materials International; 2015.

39. ASTM. Standard Test Method for Linear Drying Shrinkage of Concrete Masonry Units. West Conshohocken: American Society for Testing and Materials International; 2016.

40. ASTM. Standard Specification for Concrete Building Brick. West Conshohocken: American Society for Testing and Materials International; 2016.

41. de Sensale GR. Strength development of concrete with rice-husk ash. Cem Concr Compos. 2006;28:158-60.

42. Ganesan K, Rajagopal K, Thangavel K. Rice husk ash blended cement: assessment of optimal level of replacement for strength and permeability properties of concrete. Constr Build Mater. 2008;22:1675-83.

43. ASTM. Standard Specification for Nonloadbearing Concrete Masonry Units. West Conshohocken: American Society for Testing and Materials International; 2017

44. BSI. Specification for Masonry Units - Part 3: Aggregate Concrete Masonry Units (Dense and Light-weight Aggregates). London: British Standards Institution; 2015.

45. BSI. Eurocode 8: Design of Structures for Earthquake Resistance - Part 1: General Rules, Seismic Actions and Rules for Buildings. London: British Standards Institution; 2005

Ready to submit your research? Choose BMC and benefit from:

- fast, convenient online submission

- thorough peer review by experienced researchers in your field

- rapid publication on acceptance

- support for research data, including large and complex data types

- gold Open Access which fosters wider collaboration and increased citations

- maximum visibility for your research: over $100 \mathrm{M}$ website views per year

At $\mathrm{BMC}$, research is always in progress.

Learn more biomedcentral.com/submissions 